\title{
Erratum: Tremblay, O., et al. Several New Putative Bacterial ADP-Ribosyltransferase Toxins Are Revealed from In Silico Data Mining, Including the Novel Toxin Vorin, Encoded by the Fire Blight Pathogen Erwinia amylovora. Toxins 2020, 12, 792
}

\author{
Olivier Tremblay, Zachary Thow (D), Jennifer Geddes-McAlister (D) and A. Rod Merrill *(D) \\ Department of Molecular and Cellular Biology, University of Guelph, Guelph, ON N1G 2W1, Canada; \\ otrembla@uoguelph.ca (O.T.); zthow@uoguelph.ca (Z.T.); jgeddesm@uoguelph.ca (J.G.-M.) \\ * Correspondence: rmerrill@uoguelph.ca; Tel.: +1-519-824-4120 (ext. 53806)
}

check for updates

Citation: Tremblay, O.; Thow, Z.; Geddes-McAlister, J.; Merrill, A.R. Erratum: Tremblay, O. et al.

Several New Putative Bacterial ADP-Ribosyltransferase Toxins Are Revealed from In Silico Data Mining, Including the Novel Toxin Vorin, Encoded by the Fire Blight Pathogen Erwinia amylovora. Toxins 2020, 12, 792. Toxins 2021, 13, 229. https://doi.org/ $10.3390 /$ toxins 13030229

Received: 22 February 2021

Accepted: 16 March 2021

Published: 22 March 2021

Publisher's Note: MDPI stays neutral with regard to jurisdictional claims in published maps and institutional affiliations.

Copyright: (c) 2021 by the authors. Licensee MDPI, Basel, Switzerland. This article is an open access article distributed under the terms and conditions of the Creative Commons Attribution (CC BY) license (https:// creativecommons.org/licenses/by/ $4.0 /)$.
The authors wish to make the following corrections to this paper [1]:

\section{Change in Authorship (Add One New Author)}

In the original paper [1], Jennifer Geddes-McAlister was not included as an author in the published article. Jennifer Geddes-McAlister also contributed to investigation, formal analysis, supervision for this research. The corrected Author Contributions Statement appears here. The authors apologize for any inconvenience caused and state that the scientific conclusions are unaffected. The original article has been updated.

The authorship change from

Olivier Tremblay, Zachary Thow and A. Rod Merrill * Department of Molecular and Cellular Biology, University of Guelph, Guelph, ON N1G 2W1, Canada; otrembla@uoguelph.ca (O.T.); zthow@uoguelph.ca (Z.T.)

to

Olivier Tremblay, Zachary Thow, Jennifer Geddes-McAlister and A. Rod Merrill * Department of Molecular and Cellular Biology, University of Guelph, Guelph, ON N1G 2W1, Canada; otrembla@uoguelph.ca (O.T.); zthow@uoguelph.ca (Z.T.); jgeddesm@uoguelph.ca (J.G.-M.).

\section{Change in Author Contributions}

Conceptualization, O.T., Z.T. and A.R.M.; Funding acquisition, A.R.M.; Investigation, O.T., Z.T., J.G.-M. and A.R.M.; Formal analysis, J.G.-M.; Supervision, J.G.-M.; Writingoriginal draft, O.T.; Writing_review and editing, O.T., Z.T. and A.R.M. All authors have read and agreed to the published version of the manuscript.

\section{Reference}

1. Tremblay, O.; Thow, Z.; Merrill, A.R. Several New Putative Bacterial ADP-Ribosyltransferase Toxins Are Revealed from In Silico Data Mining, Including the Novel Toxin Vorin, Encoded by the Fire Blight Pathogen Erwinia amylovora. Toxins 2020, 12, 792. [CrossRef] [PubMed] 